\title{
Original Research \\ Structure and Functional Metabolism of Bacterial Communities on Leaves of Typical Urban Greening Tree Species
}

\author{
Hai-han Zhang*, Sheng-nan Chen, Ting-lin Huang \\ School of Environmental and Municipal Engineering, Xi'an University of Architecture and Technology, \\ Xi'an 710055, Shaanxi Province, P. R. China
}

Received: 26 August 2014

Accepted: 19 October 2014

\begin{abstract}
Urban greening tree species play a critical role in beautifying city environmental conditions and cleaning air, especially in arid and semi arid areas of northwestern China. To better understand the characteristics of bacterial communities loaded on the surface of typical urban greening tree species, scanning electron microscopes (SEM) and the substrate utilization profiling (BIOLOG) method were employed to evaluate the bacterial structure and functional community diversity associated with the leaves of Platanus orientalis, Robinia pseudoacacia, Prunus cerasifera, and Diospyros kaki growing in Xi' an City. The results showed that the dominated bacterial species were sphaerita and bacillus observed by SEM. R. pseudoacacia and P. cerasifera were dominated by sphaerita, but $P$. orientalis and $D$. kaki were dominated by bacillus. The BIOLOG metabolic profile results revealed that the highest Average Well Color Development $\left(A W C D_{590 \mathrm{~nm}}\right)$ was $D$. kaki, which was 4.3 times higher than that of $P$. orientalis $(P<0.01)$. The $A W C D$ value was ordered as: $D$. kaki $>$ P. cerasifera $>$ R. pseudoacacia $>$ P. orientalis. Meanwhile, the highest species richness, species diversity, and Shannon's diversity index were also found in $D$. kaki with $29,4.79$, and 3.09 , respectively $(P<0.05)$. The utilization of amino acids, carboxylic acids, carbohydrates, amines, polymers, and phenolic compounds by leaf bacteria was different. Amines and Polymers were most utilized by P. orientalis and R. pseudoacacia, respectively. Phenolic compounds were most metabolized in D. kaki. The principle component analyses (PCA) revealed that $\mathrm{PC} 1$ and $\mathrm{PC} 2$ explained $36.41 \%$ and $11.99 \%$ of the total variation, respectively. There is a significant different sole carbon source utilization image of surface bacterial functional communities associated with the leaves of P. orientalis, R. pseudoacacia, P. cerasifera, and D. kaki growing in Xi' an City. The leaf of D. kaki can maintain more bacterial functional community diversity than others, and it can be used as the pioneer city greening afforestation tree species in Xi'an City, Shaanxi Province.
\end{abstract}

Keywords: urban greening tree, leaf-associated bacteria, scanning electron microscopes, functional community diversity, principle component analyses

\section{Introduction}

Urban environmental conditions are seriously influenced by airborne particulates [1]. With the development of

*e-mail: haihanzhang2005@163.com the economy in northwestern China, whole cities were shrouded in a pollution haze; air pollution was a serious threat to people's health, especially in the winter. Within a city, urban green tree species exist in a wide range of artificial buildings and several natural environments [2]. Urban green tree species can be known as the lungs of the city. Urban green trees are continuously exposed to high levels 
of different types of air pollutants; several tree species can intercept the particulate matter and clean the air in the city. Citizens also realized the importance of planting trees in the city. Sæbø et al. [3] reported that urban tree species differences in particulate matter accumulation on leaf surfaces, and suggested efficient green tree species and planting designs could decrease human exposure to urban air pollutants.

The characteristics of the urban tree leaf have been determined over decades [3, 4]. Hee-Jae Hwang et al. [4] examined the submicron and ultrafine soot particle removal by leaves of Pinus densiflora, Taxus cuspidata, Platanus occidentalis, Zelkova serrata, and Ginkgo biloba, and suggested that removal of airborne soot particles could be affected by the surface roughness of urban green tree leaves. Fatemeh Kardel et al. [5] investigated the leaf saturation isothermal remanent magnetization with anatomical, morphological, and physiological tree leaf characteristics for assessing urban habitat quality, and revealed that urban habitat quality can be monitored with leaf saturation isothermal remanent magnetization. Fang Zhiguo et al. [6] studied the median diameters and size distributions of airborne microbes in three functional regions in Beijing, and suggested that there were no significant variations in microbial median diameters, and the distributions of airborne actinomycetes were completely opposite to fungal spore. However, the literature on the surface leaf microbial communities associated with the typical urban tree species is limited [7].

With the development of the molecular method, several cultural independent method based on polymerase chain reaction-Denaturing Gradient Gel Electrophoresis (PCRDGGE) was developed [8]. Noga Qvit-Raz et al. [9] used DGGE to explore the biogeographical diversity of leaf-associated microbial communities from salt-secreting Tamarix trees of the Dead Sea region, and found a significant difference of bacterial communities between the trees sampled at the same site and different geographical locations. A culturedependent method named BIOLOG has been used to determined bacterial community functional diversity from tree rehizosphere soil [10], drinking water reservoir sediment [11], reservoir water [12], and water level fluctuation zone environmental conditions [13] for decades. Unfortunately, fewer researchers used BIOLOG to exam surface leaf-associated microbial community functional diversity.

To this end, four typical urban green tree species, including Platanus orientalis, Robinia pseudoacacia, Prunus cerasifera, and Diospyros kaki in arid and semiarid areas of Xi'an City were selected. Based on the scanning electron microscopes (SEM) and substrate utilization profiling (BIOLOG) method, the objective of this work was to evaluate the bacterial structure and functional community diversity associated with the leaves of Platanus orientalis, Robinia pseudoacacia, Prunus cerasifera, and Diospyros kaki growing in Xi'an City. The results from this study will give insightful information on the urban green tree species intercept bacteria ability, and functional diversity of the surface bacterial community associated with the leaves of pioneer city forestation tree species.
Table 1. Species richness $(R)$, species diversity $(U)$, and Shannon's diversity $\left(H^{\prime}\right)$ index of surface bacterial functional communities associated with the leaves of urban green tree species, including Platanus orientalis, Robinia pseudoacacia, Prunus cerasifera, and Diospyros kaki growing in Xi'an City, Shaanxi Province.

\begin{tabular}{|c|c|c|c|}
\hline $\begin{array}{c}\text { Urban green } \\
\text { tree species }\end{array}$ & $\begin{array}{c}\text { Species } \\
\text { richness }(R)\end{array}$ & $\begin{array}{c}\text { Species } \\
\text { diversity }(U)\end{array}$ & $\begin{array}{c}\text { Shannon's } \\
\text { diversity }\left(H^{\prime}\right)\end{array}$ \\
\hline $\begin{array}{c}\text { Platanus } \\
\text { orientalis }\end{array}$ & $19 \pm 2.1 \mathrm{C}$ & $1.78 \pm 0.02 \mathrm{C}$ & $2.33 \pm 0.04 \mathrm{C}$ \\
\hline $\begin{array}{c}\text { Robinia } \\
\text { pseudoacacia }\end{array}$ & $25 \pm 3.5 \mathrm{~B}$ & $2.69 \pm 0.05 \mathrm{~B}$ & $2.84 \pm 0.03 \mathrm{~B}$ \\
\hline $\begin{array}{c}\text { Prunus } \\
\text { cerasifera }\end{array}$ & $26 \pm 2.6 \mathrm{~B}$ & $2.97 \pm 0.04 \mathrm{~B}$ & $2.87 \pm 0.04 \mathrm{~B}$ \\
\hline Diospyros kaki & $29 \pm 1.6 \mathrm{~A}$ & $4.79 \pm 0.02 \mathrm{~A}$ & $3.09 \pm 0.01 \mathrm{~A}$ \\
\hline
\end{tabular}

The data represent the means and standard error $(n=3)$.

The same capital letter after the data represents no significant difference by Tukey-Kramer HSD $(P<0.05)$.

\section{Materials and Methods}

\section{Study Site}

The study site was located in Xi'an City, Shaanxi Province, northwestern China $\left(33^{\circ} 39^{\prime}-34^{\circ} 45^{\prime} \mathrm{N}, 107^{\circ} 40^{\prime}\right.$ $109^{\circ} 49^{\prime}$ E). Xi'an is the capital of Shaanxi Province, which is located in arid and semiarid regions. Xi'an city plain area belongs to a warm, temperate semi-humid continental monsoon climate with distinct wet and dry seasons and changes in temperature. The annual average temperature is $13^{\circ} \mathrm{C}$ $13.7^{\circ} \mathrm{C}$, the coldest month is January, with an average temperature of $-1.2^{\circ} \mathrm{C}-0.0^{\circ} \mathrm{C}$, the hottest month is July, the aver-
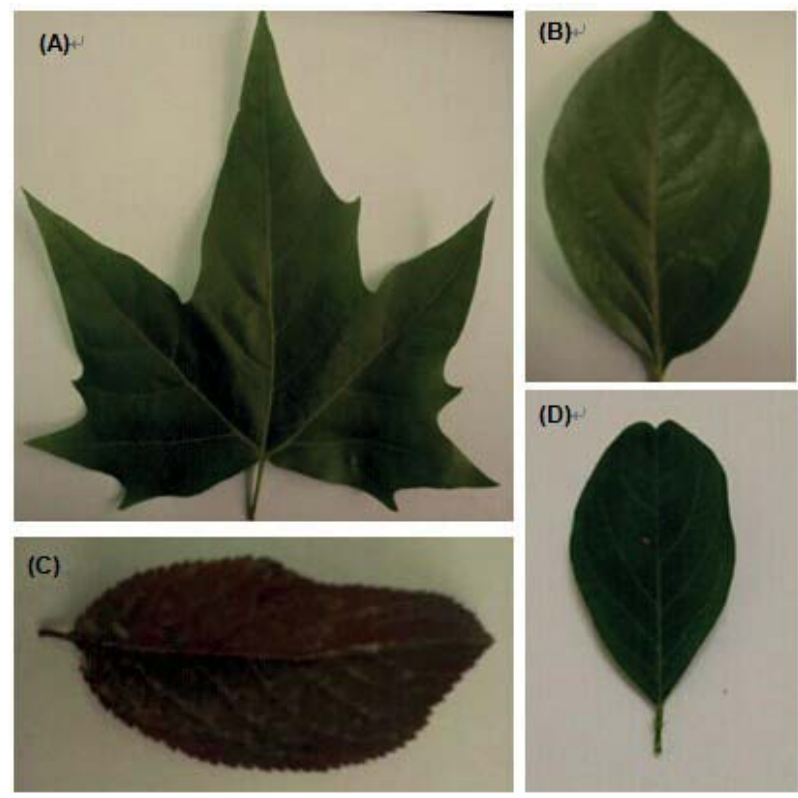

Fig. 1. Leaf morphological characteristics of urban green tree species, including (A) Platanus orientalis, (B) Diospyros kaki, (C) Prunus cerasifera, and (D) Robinia pseudoacacia growing in Xi'an City, Shaanxi Province. 
Table 2. Variance analysis of utilization of amino acids, carboxylic acids, carbohydrates, amines, polymers, and phenolic compounds in the ECO plate by surface bacterial functional communities associated with the leaves of urban green tree species, including Platanus orientalis, Robinia pseudoacacia, Prunus cerasifera, and Diospyros kaki growing in Xi'an City, Shaanxi Province.

\begin{tabular}{|l|c|c|c|c|c|c|}
\hline \multicolumn{1}{|c|}{ Urban green tree species } & Amino acids & $\begin{array}{c}\text { Carboxylic } \\
\text { acids }\end{array}$ & Carbohydrates & Amines & $\begin{array}{c}\text { Phenolic } \\
\text { compounds }\end{array}$ & Polymers \\
\hline P. orientalis & 0.201 & 0.191 & 0.081 & 0.324 & 0.043 & 0.186 \\
\hline R. pseudoacacia & 0.352 & 0.206 & 0.365 & 0.388 & 0.159 & 0.573 \\
\hline P. cerasifera & 0.414 & 0.237 & 0.425 & 0.307 & 0.300 & 0.580 \\
\hline D. kaki & 0.678 & 0.481 & 0.679 & 0.870 & 0.922 & 0.693 \\
\hline
\end{tabular}

P. orientalis, R. pseudoacacia, P. cerasifera, and D. kaki represent Platanus orientalis, Robinia pseudoacacia, Prunus cerasifera, and Diospyros kaki, respectively.

age temperature is $26.3^{\circ} \mathrm{C}-26.6^{\circ} \mathrm{C}$, annual rainfall is $522.4-$ $719.5 \mathrm{~mm}$, annual sunshine time is $1646.1-2114.9$ hours.

\section{Sampling Process}

In Xi' an City the main urban greening tree species are as follows: Sophora japonica, ginkgo, Ligustrum lucidum, Platanus orientalis, weeping willow, cherry, pomegranate, sweet scented osmanthus, crape myrtle, hibiscus, Prunus cerasifera, Parthenocissus quinquefolia, Ligustrum lucidum, Berberis thunbergii, Pittosporum tobira, and so on. In May 2014, sampling was conducted in Yanta District Road, Xi'an City, belonging to the downtown area. Air pollution is serious in the sampling area. Platanus orientalis, Robinia pseudoacacia, Prunus cerasifera, and Diospyros $k a k i$ were selected. Nine individuals of each tree species were selected randomly and the leaves were cut down from the tree using sterile scissors. For each tree species, five randomly selected leaves were put in to a tiny bottle containing stationary liquid for SEM analyses. The typical leaf morphology is shown in Fig. 1. Twenty randomly selected leaves were put into the cooler at $8^{\circ} \mathrm{C}$ and immediately transported to the lab for bacterial functional diversity analysis.

\section{Scanning Electron Microscope (SEM) Determination}

Scanning electron microscope was used to determine the characteristics of surface bacterial structure associated with the leaves of Platanus orientalis, Robinia pseudoacacia, Prunus cerasifera, and Diospyros kaki. According to the standard procedure described by Fatemeh Kardel et al. [14] and Shao Linxiang [15], SEM was conduced in the Fourth Military Medical University Center for Electron Microscopy (JSM-6360LV, JSM, Japan).

\section{Leaf Bacterial Community Function Diversity Determination}

To examine the functional diversity of surface bacterial structure associated with the leaves of Platanus orientalis,
Robinia pseudoacacia, Prunus cerasifera, and Diospyros $k a k i$, the carbon substrate utilization pattern method named BIOLOG was used in this work. According to the method described in our previous studies $[12,16]$ and modified, for each urban tree species, in order to ensure the leaf area is equal, individual leaves were clipped into a circle (diameter is two). All of the above processes were operated in aseptic conditions. For BIOLOG analyses, 15 circles of each tree species were put into the triangular flask of $45 \mathrm{ml}$ sterilized $\mathrm{NaCl}$ solution $(0.85 \%, \mathrm{w} / \mathrm{v})$, and shocked 30 minutes at 130 rpm in the dark. Then the liquid was standing for $20 \mathrm{~min}$; the $150 \mu \mathrm{l}$ supernatant was loaded in each well on the ECO plate using an electronic pipette. The ECO plates were incubated at $25^{\circ} \mathrm{C}$. The absorbance of the ECO plates was determined with $24 \mathrm{~h}$ interval. For each tree species, the BIOLOG analyses were reproduced in triplicate. The BIOLOG data at 96 hours was used to calculate the functional community diversity and multivariate statistical analysis [12]. In this work, species richness $(R)$, species diversity $(U)$, and Shannon's diversity $\left(H^{\prime}\right)$ were used to evaluate the leaf bacterial functional community diversity of urban tree species. BIOLOG ECO plate contains 31 sole carbon sources, including amino acids, carboxylic acids, carbohydrates, amines, polymers, and phenolic compounds $[16,17]$.

\section{Data Analysis}

Average well color development $(A W C D)$, species richness $(R)$, species diversity $(U)$, and Shannon's diversity $\left(H^{\prime}\right)$ were calculated. The computational formulas for each index were [11-13, 16, 17]:

$$
\begin{aligned}
& A W C D=\sum\left(C_{i}-R\right) / 31, U=\sqrt{\left(\sum n_{i}^{2}\right)} \text { and } \\
& H=-\sum P_{i} \times L n P_{i} .
\end{aligned}
$$

One way ANOVA was use to show the differences with Tukey HSD test. To reveal the difference of leaf bacterial functional community diversity of tree species, principal component analysis (PCA) was performed using SPSS software (Version 16.0) for Windows. 


\section{Results and Discussion}

\section{Scanning Electron Microscope Images}

As shown in Fig. 2, the results showed that the dominated bacterial species were sphaerita and bacillus observed by SEM. $R$. pseudoacacia and P. cerasifera were dominated by sphaerita while $P$. orientalis and $D$. kaki were dominated by bacillus. Meanwhile, particulate matter was also accumulated on the surface of leaves.

\section{Leaf Bacterial Functional Community Diversity}

As shown in Fig. 3, the changing curve of $A W C D_{590 \mathrm{~mm}}$ of four tree species was different. At the beginning $(0-24 \mathrm{~h})$, the $A W C D$ value was lower, suggesting that the carbon metabolic of bacterial community on the leaf was lower and limited sole carbon sources were utilized. From 24 to $48 \mathrm{~h}$, the metabolic activity was increased steadily. During 10 days, the increased slopes were $0.09,0.05,0.04$, and 0.02 for D. kaki, P. cerasifera, R. pseudoacacia, and P. oriental$i s$, respectively. The Species richness was ordered as: $D$. kaki $(29 \pm 1.6)>P$. cerasifera $(26 \pm 2.6)>R$. pseudoacacia $(25 \pm 3.5)>P$. orientalis $(19 \pm 2.1)(F=32.12, P<0.01)$. The significant highest species diversity $(U)$ was also found in
$D$. kaki, and the lowest was in P. orientalis $(F=65.82$, $P<0.01)$. Shannon's diversity $\left(H^{\prime}\right)$ was ordered as $D$. kaki $(3.09 \pm 0.01)>P$. cerasifera $(2.87 \pm 0.04)>R$. pseudoacacia $(2.84 \pm 0.03)>P$. orientalis $(2.33 \pm 0.04)(F=13.76, P<0.05)$ (Table 1). As shown in Table 2, the utilization of amino acids, carboxylic acids, carbohydrates, amines, polymers, and phenolic compounds by leaf bacteria was different. Amines and Polymers were most utilized by $P$. orientalis and $R$. pseudoacacia, respectively. Phenolic compounds were most metabolized in $D$. kaki (Table 2).

The BIOLOG results also revealed that the highest average well color development $\left(A W C D_{590 \mathrm{~nm}}\right)$ was $D . \mathrm{kaki}$, which was 4.3 times higher than that of $P$. orientalis ( $F=46.53, P<0.01)$ (Fig. 4). The $A W C D$ value was ordered as: $D$. kaki $>P$. cerasifera $>R$. pseudoacacia $>P$. oriental$i s$. Meanwhile, the highest species richness, Species diversity and Shannon's diversity index were also found in $D$. kaki with $29,4.79$, and 3.09, respectively. The principle component analyses (PCA) revealed that $\mathrm{PC} 1$ and $\mathrm{PC} 2$ explained $36.41 \%$ and $11.99 \%$ of the total variation, respectively. $\mathrm{PC} 1$ can separate $P$. orientalis and P. cerasifera, while PC2 can separate $R$. pseudoacacia and D. kaki $(P<0.05)$ (Fig. 5). There was a significant by different sole carbon source utilization image of surface bacterial functional communities associated with the leaves of $P$. orientalis, R. pseudoacacia, P. cerasifera, and D. kaki growing in
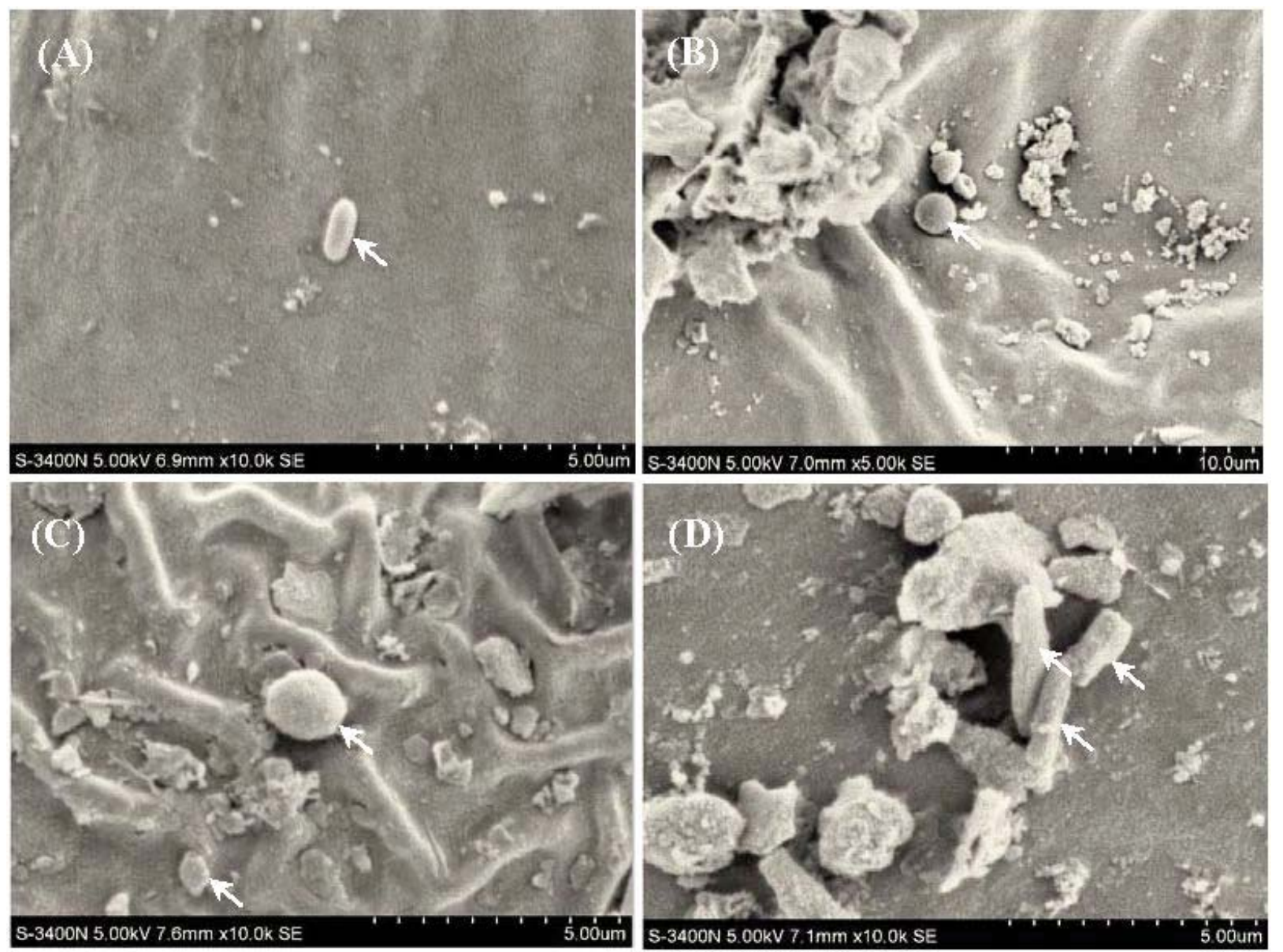

Fig. 2. Scanning electron microscopy (SEM) images of surface particulate matter and bacterial structure associated with the leaves of (A) Platanus orientalis, (B) Diospyros kaki, (C) Prunus cerasifera, and (D) Robinia pseudoacacia growing in Xi'an City, Shaanxi Province. Arrow shows the bacteria loaded on the surface of leaves. 
Xi'an City. The leaf of $D$. kaki can maintain more bacterial functional community diversity than others, and it can be used as the pioneer city greening afforestation tree species in Xi'an City, Shaanxi Province.

In this work, SEM was used to exam the particulate matter on Platanus orientalis, Robinia pseudoacacia, Prunus cerasifera, and Diospyros kaki leaves. The results showed that different urban green tree species have a different ability to hold particulate matter on the leaf. This is consistent with results from Sæbø et al. [3]. In the field study, 22 trees and 25 shrubs were examined by Sæbø et al. [3], and showed that significant differences were observed among tree species in particulate matter accumulation, Pinus sylvestris, Taxus media, Taxus baccata, Pinus mugo,

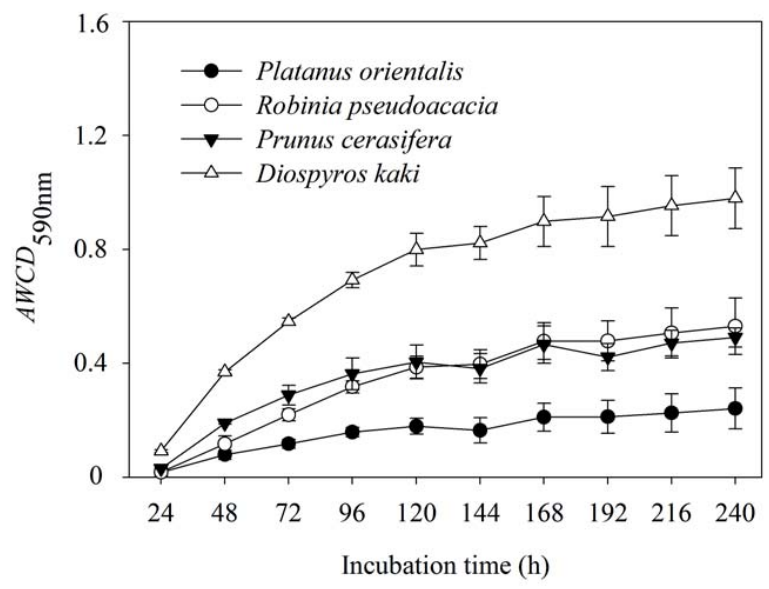

Fig. 3. The changing curve of average well color development $\left(A W C D_{590 \mathrm{~nm}}\right)$ of surface bacterial functional diversity associated with the leaves of Platanus orientalis, Diospyros kaki, Prunus cerasifera, and Robinia pseudoacacia growing in Xi'an City, Shaanxi Province.

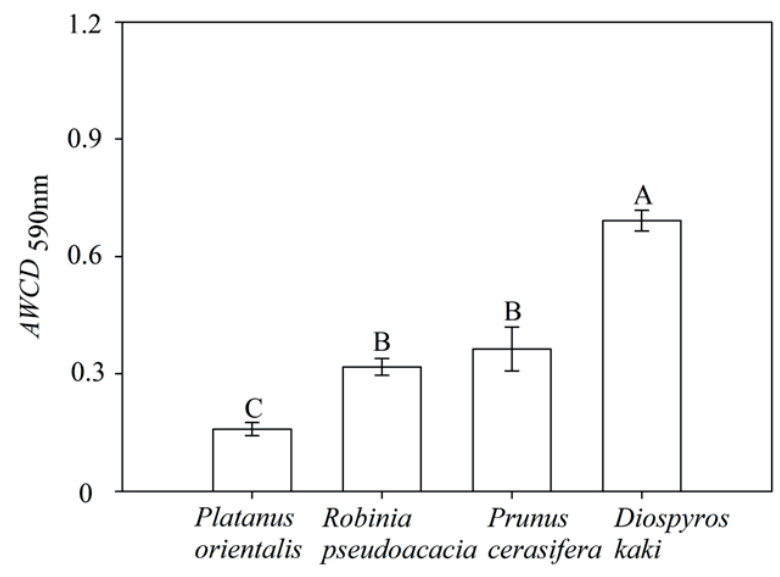

Tree species

Fig. 4. Average well color development $\left(A W C D_{590 \mathrm{~nm}}\right)$ of surface bacterial functional diversity associated with the leaves of Platanus orientalis, Diospyros kaki, Prunus cerasifera, and Robinia pseudoacacia growing in the Xi'an City, Shaanxi Province. Data were selected based on the carbon substrate utilization pattern on the ECO plate after $96 \mathrm{~h}$ incubation. The data represented the means and standard error $(n=3)$.

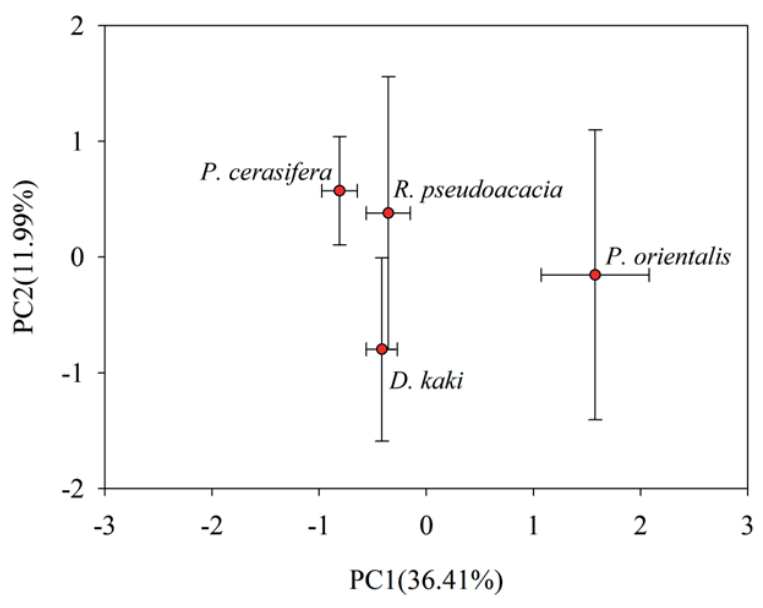

Fig. 5. Principle component analyses of surface bacterial functional diversity associated with the leaves of Platanus orientalis, Diospyros kaki, Prunus cerasifera, and Robinia pseudoacacia growing in Xi'an City, Shaanxi Province. The data represent the means and standard error $(\mathrm{n}=3)$. Principle components 1 and 2 (Abbr. PC1 and PC2) explained $36.41 \%$ and $11.99 \%$ of the total variance, respectively.

Stephanandra incisa, and Betula pendula were efficient species in capturing particulate matter accumulation on leaves. The important explanation for this phenomenon is different tree species have different leaf traits, including leaf hair and wax content.

Meanwhile, we also determined the bacterial community metabolic characteristics on the surface leaves of Platanus orientalis, Robinia pseudoacacia, Prunus cerasifera, and Diospyros kaki. The results suggest that leaves were colonized by complex bacterial communities. The sole carbon sources metabolic profiles were distinct among the tested tree species. The phyllosphere microbial community could have a beneficial role in plant growth and clean air, and can be shaped by several factors [7]. Wang et al. [18] revealed that Bacillus thuringiensis has a significant effect on the bacterial communities within the phyllosphere of cotton and amaranth, but not rice. Rico et al. [19] also found that surface leaf community structure of N-2 fixers was influenced seasonally and inter-annually by environmental conditions, and drought treatment could increase the richness of the microbial community. In Shaanxi Province, the area is arid and semiarid of northwestern China. It is consistent with the report. Phyllosphere microbial communities have been determined on a number of different plants using cultivation-dependent and independent methods [20]. Remus-Emsermann et al. [20] used fluorescence in situ hybridization (FISH) to explore bacterial communities of Arabidopsis thaliana leaf, and found on average $5.4 \times 10^{6}$ bacteria per square centimeter leaf surface. From the present work, BIOLOG-ECO plate can be used for a better understanding of the phyllosphere microbial ecology in the future. The results generated from the present work might contribute toward understanding the relationship between urban green tree species and its leaf-associated bacterial community. Accordingly, D. kaki could be suggested as the 
pioneer city greening afforestation tree species in $\mathrm{Xi}$ 'an City, Shaanxi Province. The phyllosphere of urban green tree species is inhabited by diverse microorganisms, including bacteria, fungi, and actinomycetes, therefore more studies were necessary for determining phyllosphere fungal and actinomycic communities in the future.

\section{Acknowledgements}

This work was funded by the Shaanxi Provincial Natural Science Foundation (No. 2013JQ7012) and the Youth Science and Technology Foundations of Xi'an University of Architecture and Technology (No. QN1311, No. RC1242). We also thank the anonymous reviewers for their insightful suggestions and comments on an earlier version of the manuscript.

\section{References}

1. DELJANIN I. V., TOMASEVIC M. N., ANICIC UROSEVIC M. P., ANTANASIJEVIC D. Z., PERI'C-GRUJIC A A., RISTIC M. D. Lead isotopic composition in tree leaves as tracers of lead in an urban environment. Ecological Indicators. 45, 640, 2014.

2. ZHANG H., JIM CY. Contributions of landscape trees in public housing estates to urban biodiversity in Hong Kong. Urban Forestry and Urban Greening. 13, 272, 2014.

3. SABO A., POPEK R., NAWROT B., HANSLIN H.M., GAWRONSKA H., GAWRONSKI S.W. Plant species differences in particulate matter accumulation on leaf surfaces. Sci. Total Environ. 427-428, 347, 2012.

4. HWANG H.J., YOOK S.J., AHN K.H. Experimental investigation of submicron and ultrafine soot particle removal by tree leaves. Atmos. Environ. 45, 6987, 2011.

5. KARDEL F., WUYTS K., KHAVANINZHADEH A. R., WUYTACK T., BABANEZHAD M., SAMSON R. Comparison of leaf saturation isothermal remnant magnetization (SIRM) with anatomical, morphological and physiological tree leaf characteristics for assessing urban habitat quality. Environ. Pollut. 183, 96, 2013.

6. FANG Z., OUYANG Z., HU L., WANG X., LIN X. Study on median diameters and size distributions of airborne microbes in three functional regions in Beijing. Acta Ecologica Sinica. 25, (12), 3220, 2005.

7. VORHOLT J.0A. Microbial life in the phyllosphere. Nature Reviews Microbiology, 10, (12), 828, 2012.

8. MUELLER T., RUPPEL S. Progress in cultivation-independent phyllosphere microbiology. FEMS Microbiol. Ecol. 87, (1), 2, 2014
9. NOGA QVIT-RAZ, OMRI M. FINKEL, TAGHLEB M. AL-DEEB, HANAN I. MALKAWI, MUNA Y. HINDIYEH, EDOUARD JURKEVITCH, SHIMSHON BELKIN. Biogeographical diversity of leaf-associated microbial communities from salt-secreting Tamarix trees of the Dead Sea region. Res. Microbiol. 163, 142, 2012.

10. ZHANG H., TANG M., CHEN H., TIAN Z. Effects of inoculation with ectomycorrhizal fungi on microbial biomass and bacterial functional diversity in the rhizosphere of Pinus tabulaeformis seedlings. Eur. J. Soil Biol. 46, (1), 55, 2010.

11. ZHANG H., HUANG T., CHEN S., GUO L., LIU T., YANG X. Microbial community functional diversity and enzymatic activity in the sediments of drinking water reservoirs, Northwest China. Desalination and Water Treatment. 52, (7-9), 1608, 2014.

12. ZHANG H., HUANG T., CHEN S., GUO L., YANG X., LIU T. Spatial pattern of bacterial community functional diversity in a drinking water reservoir, Shaanxi Province, Northwest China. Journal of Pure and Applied Microbiology. 7, (3), 1647, 2013.

13. ZHANG H., HUANG T., YANG X., MA W. Soil dehydrogenase activity and bacterial community diversity in the water level fluctuation zone of a drinking water reservoir. Journal of Pure and Applied Microbiology. 7, (3), 2451, 2013.

14. KARDEL F., WUYTS K., BABANEZHAD M., WUYTACK T., ADRIAENSSENS S., SAMSON R. Tree leaf wet ability as passive bio-indicator of urban habitat quality. Environ. Exp. Bot. 75, 277, 2012.

15. SHAO L., ZHANG J., LIU Y. Observation of leaves of eight Cupressaceae species by SEM. Journal of Zhejiang Normal University. 31, (2), 195, 2008.

16. GARLAND JL., MILLS AL. Classification and characterization of heterotrophic microbial communities on the basis of patterns of community-level sole-carbon-source utilization. Appl. Environ. Microb. 57, 2351, 1991.

17. CHOI K.H., DOBBS F.C. Comparison of two kinds of Biolog microplates (GN and ECO) in their ability to distinguish among aquatic microbial communities. Journal of Microbiology Methods. 36, 203, 1999.

18. WANG X., XUE Y., HAN M., BU Y., LIU C. The ecological roles of Bacillus thuringiensis within phyllosphere environments. Chemosphere. 108, 258, 2014.

19. RICO L., OGAYA R., TERRADAS J., PENUELAS J. Community structures of N-2-fixing bacteria associated with the phyllosphere of a Holm oak forest and their response to drought. Plant Biology. 16, (3), 586, 2014.

20. REMUS-EMSERMANN M. N. P., LUECKER S., MUELLER D. B., POTTHOFF E., DAIMS H., VORHOLT J. A. Spatial distribution analyses of natural phyllospherecolonizing bacteria on Arabidopsis thaliana revealed by fluorescence in situ hybridization. Environ. Microbiol. 16, (7), 2329,2014 